Dept. of Bacteriology,

Animal Health Research Institute, Shebin El-Koom.

\title{
MICROBIOLOGICAL STUDIES ON SALMONELLA MICROORGANISM IN SOME MEAT PRODUCTS
}

(With 4 Tables and One Photo)

By

\section{EMAN M. SHARAF; EBTESAM M. MEZYED* and GEHAN S. AFIFI**}

Serology Unit, Animal Health Research Institute, Dokki, Cairo.

**Fac. Vet. Med., Moshotohor, Banha Univ.

(Received at 24/11/2010)

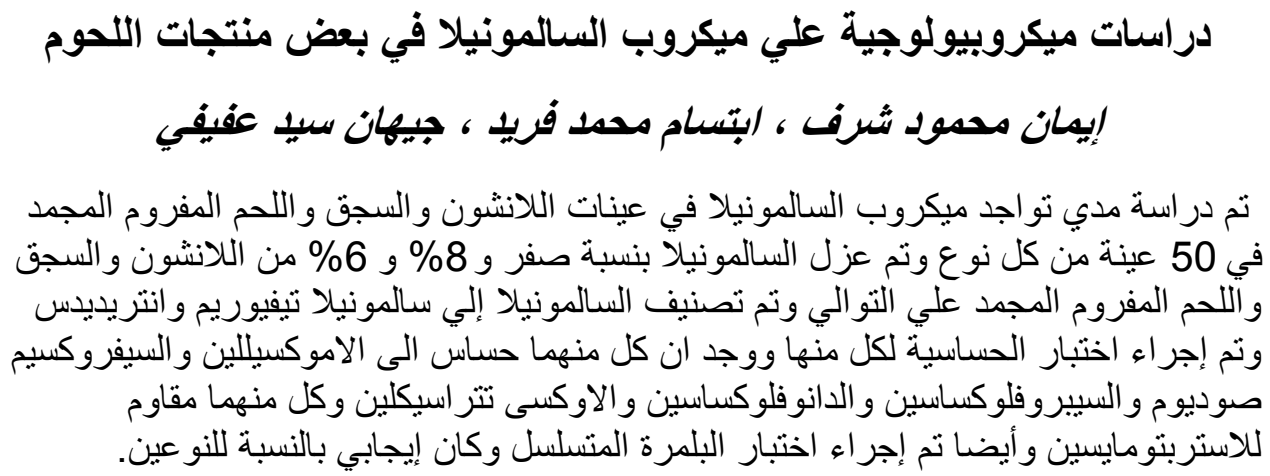

\section{SUMMARY}

Hundred and fifty random samples of various meat products represented by luncheon, sausage and frozen minced meat (50 of each) were collected from different markets for detection of Salmonella spp., Obtained results declared that Salmonella could be detected in zero, 8 and $6 \%$ of the examined samples of luncheon, sausage and frozen minced meat respectively. The recovered salmonellae were serotyped as Salmonella typhimurium and Salmonella enteritidis. The in vitro senstivity tests for the isolated bacteria were determined, Salmonella typhimurium and Salmonella enteritidis were sensitive to Amoxicillin, cefuroxime sod. Ciprofloxacin, Danofloxacin and oxytetracycline and were resistant to streptomycin. Salmonella typhimurium and Salmonella enteritidis can be detected by Real-Time PCR when used Quantitect probe RT-PCR kit cat. no. 204443 which based on fluoroqenic primers and probe (TAMRA dye).

Key words: Salmonella microorganism, meat products, minced meat, sausage, luncheon, antibiogram, PCR. 


\section{INTRODUCTION}

Meat products such as luncheon, sausage and minced meat have a popularity because they represent quick, easy prepared meat meals and solve the problem of the storage in fresh meat of high price which is not within the reach of large number of families with limited income (Mohamed 2006). On the other side, meat products are liable to harbour different types of microorganisms through along chain of handling, processing, distribution and storage as well as preparation (Hassanien, 2004). Within this respect meat in general and poultry in particular are the commonest source of food borne diseases and have been frequently linked to outbreaks of food poisoning by Salmonella (Antunes et al., 2003). Salmonella spp. typically cause an intestinal infection with or without fever, the spread to human is usually caused by consumption of contaminated food stuffs (Bhan et al., 2005). Salmonella is one the most common cause of food borne diseases (Tirado and Schmidt, 2001) for this reason, the number of rapid test methods for Salmonella has grown rapidly in the last decade. PCR and real time PCR have become powerful tools for detection of pathogens in food. (Malorny et al., 2003 and 2004). The real time PCR in food borne outbreak investigations provides an opportunity in food and clinical settings (Burkhard et al., 2004). This study was undertaken for isolation of Salmonella from some meat products and identification of the isolates by real- time PCR.

\section{MATERIALS and METHOD}

\section{I- Collection of samples:}

A total of 150 random samples of luncheon, sausage and frozen raw minced meat ( 50 of each) were collected from different markets in Egypt an examined for the presence of Salmonella species.

II- Isolation and Identification. (FAO, 1979).

The method for isolation and identification of Salmonella recommended by Edwards and Ewing (1972), Cowan and Steel (1975) and FAO (1979) was followed.

\section{Pre-enrichment}

$25 \mathrm{gm}$ of each sample were blended with $225 \mathrm{ml}$ of buffered peptone water and transfered aseptically to a sterile $500 \mathrm{ml}$ flask then incubated at $37^{\circ} \mathrm{C}$ for $10-20 \mathrm{~h}$. 


\section{Enrichment}

$10 \mathrm{ml}$ of each pre-enrichment medium were transfered to $100 \mathrm{ml}$ tetrathionat broth medium and another $10 \mathrm{ml}$ to $100 \mathrm{ml}$ selenite $\mathrm{F}$. broth medium previously warmed to $42-43^{\circ} \mathrm{C}$ and incubated at $42-43^{\circ} \mathrm{C}$ for $48 \mathrm{~h}$.

\section{Plating on selective media:}

Brilliant green agar, MacConkey agar and Salmonella-shigella agar media were streaked from each enrichment flask and incubated at $37^{\circ} \mathrm{C}$ for 24h., then examined for typical colonies for Salmonella.

Typical or suspected colonies were selected from each selective medium and streaked on nutrient agar medium which incubated at $37^{\circ} \mathrm{C}$ for $24 \mathrm{~h}$.

Morphological, biochemical and serological confirmation were performed according to Edwards and Ewing (1972), and Cowan and Steel (1975).

\section{III- Antibiogram:}

Salmonella isolates were tested for sensitivity to 15 antibiotics by the disc and agar diffusion method. The interpretation of the results was carried out according to NCCLS (2002).

\section{V- Real-time PCR (Petra et al., 2005):}

A real-time PCR assay was developed based on fluorogenic primers and probe, sal-F (5' -GCGTTCTGAACCTTTGGTAATAA-3'), sal-R (5'CGTTCGGGCAATTGGTTA-3'), and probe (5'-FAMTGGCGGTGGGTTTGTTGTCTTCT-TAMRA-3') used for amplification of a 102-pbregio on of the inVA gene of Salmonella. The PCR mixture consisted of $12.5 \mu 12 \mathrm{X}$ Quantitect probe RT-PCR master Mix, $0.2 \mu 1$ primer F 50 pmol, $0.2 \mathrm{~V}$ primer R $50 \mathrm{pmol}, 0.25 \mathrm{~V}$ probe 30 pmol $4-5 \mu 1$ RNase free water 2-5 $\mu$ l template RNA (Quantitect probe RT-PCR kit catalogue no-20 4443).

\section{RESULTS}

Table 1: Incidence of Salmonella in the examined samples of meat products

\begin{tabular}{|l|c|c|c|}
\hline \multicolumn{1}{|c|}{ Samples } & No of samples & Positive samples & $\%$ \\
\hline Luncheon & 50 & - & - \\
\hline Sausage & 50 & 4 & 8 \\
\hline Frozen minced meat & 50 & 3 & 6 \\
\hline
\end{tabular}


Table 2: Serotyping of Salmonella isolated from the examined samples of meat products $(\mathrm{N}=50)$

\begin{tabular}{|c|c|c|c|c|c|c|}
\hline \multirow{2}{*}{ Serotypes } & \multicolumn{6}{|c|}{ Frequency of isolation } \\
\cline { 2 - 7 } & \multicolumn{2}{|c|}{ Luncheon } & \multicolumn{2}{c|}{ Sausage } & \multicolumn{2}{c|}{ Frozen minced meat } \\
\cline { 2 - 7 } & No & $\%$ & No & $\%$ & No & $\%$ \\
\hline \multirow{2}{*}{$\begin{array}{c}\text { S.typhimurium } \\
\text { S. enteritidis }\end{array}$} & - & - & 2 & 4 & 2 & 4 \\
\cline { 2 - 7 } & - & - & 2 & 4 & 1 & 2 \\
\hline
\end{tabular}

Table 3: Antigenic formula of Salmonella recovered from meat products samples.

\begin{tabular}{|l|c|c|c|}
\hline \multirow{2}{*}{ Isolated Salmonella } & \multicolumn{3}{|c|}{ Antigenic formula } \\
\cline { 2 - 4 } & $\mathrm{O}$ & Phase 1 & Phase 2 \\
\hline S.typhimurium & $1,4,(5), 12$ & $\mathrm{I}$ & 1,2 \\
\hline S. enteritidis & $1,9,12$ & $\mathrm{~g}, \mathrm{~m}$ & {$[1,7]$} \\
\hline
\end{tabular}

Table 4: Antibiogram patterns of isolated Salmonella serovars

\begin{tabular}{|l|c|c|c|c|}
\hline $\begin{array}{c}\text { Antibiotic and } \\
\text { chemotherapeutic agent }\end{array}$ & Conc. & Symbol & $\begin{array}{c}\text { Salmonella } \\
\text { typhimurium }\end{array}$ & $\begin{array}{c}\text { Salmonella } \\
\text { enteritidis }\end{array}$ \\
\hline Amoxicillin & 10 & AML & S & S \\
\hline Ampicillin & 10 & AMP & M & S \\
\hline Cefoperazone & 75 & CFP & M & M \\
\hline Cefotaxime & 30 & CTX & M & M \\
\hline Cefuroxime sod & 30 & C & S & S \\
\hline Ciprofloxacin & 5 & CIP & S & S \\
\hline Colistin sulphate & 25 & CT & S & S \\
\hline Danofloxacin & 5 & DFX & S & S \\
\hline Flumequine & 30 & UB & S & S \\
\hline Enrofloxacin & 5 & ENR & S & S \\
\hline Nalidixic acid & 30 & NA & S & S \\
\hline Oxalinic acid & $2 \mathrm{ug}$ & OA & M & M \\
\hline Oxytetracycline & $30 \mathrm{u}$ & OT & S & S \\
\hline Streptomycin & $10 \mathrm{ug}$ & S & R & R \\
\hline S & & & & \\
\hline
\end{tabular}

$\mathrm{S}=$ sensitive

$\mathrm{M}=$ Moderate sensitivity

$\mathrm{R}=$ Resistant 
Photo 1: Analysis of Real-time PCR for Salmonella typhimurium and Salmonella enteritidis.

\section{DISCUSSION}

Meat and meat products are considered as a major vehicle of most reported outbreaks of foodborne disease. Epidemiology data have identified improperly handled meat products as important vehicles for infection (ICMSF, 1978), Salmonella remains as one of the major food borne health hazards and meat plays an important role, as a reservoir, in disseminating Salmonella (Mohamed, 2006).

In present study a total of one handred and fifty random samples of meat products (50 samples of luncheon, 50 samples of fresh sausage and 50 samples of frozen minced meat) were examined for salmonellae. Results obtained in Table (1) revealed zero, 8 and 6\%that Salmonella were detected in the examined luncheon, sausage and frozen minced meat respectively. These results agree with that reported by Saleh (1991); Edris (1993); Moussa et al. (1993); Fathi et al. (1994); Aiedia (1995); Abd-ElAziz et al. (1996); Ouf (2001) and Eleiwa (2003). The result disagrees with that reported by Mohamed (1988) who recorded that salmonellae could not be detected in the examined luncheon samples. From the results recorded in Table (1) it's clear that fresh sausage had higher incidence $(8 \%)$ of Salmonella contamination followed by frozen minced meat $(6 \%)$. High 
incidence of salmonellae in fresh sausage may be due to faults in certain practices of slaughtering and handling processes such as the use of contaminated knives, tools, rags, saws, boards ....etc as well as unhygienic slaughtering, dressing, washing, transporting, handling and cutting in abattoirs and butcher shops. The high incidence of salmonellae in frozen minced meat may be due to cutting and contamination of meat besides the increase in its water and oxygen contents as well as contamination from grinders, dir, packaging materials and hands of workers. Temperature rise $\left(2-4^{\circ} \mathrm{C}\right)$ during grinding could also increase the incidence of salmonellae organisms (Field et al., 1977). The absence of salmonellae in luncheon meat may be due to the addition of food additives such as spices and preservatives, which have an antimicrobial activity and inhibit survival and multiplication of micro-organisms (Libby 1975). This also may be attributed to the exposure to high temperature during processing and cooking procedures.

From the results recorded in Table (2) it's clear that four Salmonella serovars were identified from sausage samples, two (4\%) strains as S. typhimurium and two (4\%) strains as S.enteritidis. Nearly similar results were obtained by Rao and Nandy (1977). It's evident that three Salmonella serovars were isolated from the examined frozen minced meat samples and identified as two (4\%) strains as S. typhimurium and one $(2 \%)$ as $S$. enteritidis. These results agree with that obtained by Gobran (1985).

Antibiogram patterns (Table 4) showed that Salmonella typhimurium isolates were resistant to streptomycin and sensitive to amoxicillin, cefuroxime sod., ciprofloxacin, Danofloxacin, flumequine, Enrofloxacin and oxytetracycline. Salmonella enteritidis was similar to Salmonella typhimurium. These results are similar to those recorded by Frech and Schwarz (1998); Guerra et al. (2000); Wiuff et al. (2000) and Gebreyes et al. (2004).

Photo (2) showed that Salmonella typhimurium and Salmonella enteritidis were detected by Real-time PCR when used fluorogenic primers and TAMARA-probe used for amplification of 102-bp region of the in VA gene of Salmonella (Quantitect probe RT-PCR kit cat.no.20 4443), according to Kura et al. (1999); Livak et al. (1995); Paszko et al. (1997); Hoorfar and Radstrom (2000). Detection probability of Salmonella realtime PCR assay at serially 10- fold- diluted cell concenterations of serotype typhimurium and enteritidis reference strains was determined in the presence of 150 copies of IAC DNA. Five microliters of each suspension $\left(10^{0}\right.$ to $10^{6} \mathrm{CFU} /$ unit) was used as the template in the PCR. The graph shows a sigmoidal fit of data points generated by 30 repetitive PCRs. The 
real-time PCR in food borne outbreak investigations provides an opportunity for rapid detection of pathogens in food and clinical settings (Burkhard et al., 2004).

Apart from saving time, real-time PCR is sensitive highly specific and offers the potential for quantification, the risk of cross-contamination is significantly reduced and high-through put performance and automation are possible, since no post-PCR manipulations are required (Harnai et al., 1997; Lubeck and Hoorfar, 2003).

From the obtained results we can concluded that the possibility of contamination of meat products with such serious pathogens remains as a public health problem. Thus all precautions of proper sanitation during manufacture, handling and storage of such meat products should be adopted to control these serious pathogens and to obtain a maximum limit of safety to consumers. The RT- PCR may be considered as a rapid, sensitive highly specific and offers the potential for quantification of Salmonella isolates.

\section{REFERENCES}

Abd El-Aziz, A.S.; El-Neklawy, E.I.S.; Hussien, A. and Niazi, Z. (1996): Food poisoning microorganisms in some locally meat products. Vet. Med. J., Giza 44(4): 691-698.

Aiedia, H.A. (1995): Quality investigation into room kept traditional meat products in Egypt ph.D. Thesis (Meat Hygiene) Fac. Vet. Med., Cairo University.

Antunes, P.; Reu, C.; Sousa, J.C.; Peixe, L. and Pestana, N. (2003): Incidence of Salmonella in poultry and their susceptibility to microbial agents Int. J. Food Microbiol. 82: 97-103.

Bhan, M.K.; Bahl, R. and Bhatnagar, S. (2005): Typhoid and paratyphoid fever. Lancet 366: 749-762.

Burkhard, M.; Elisa, P.; Partick, F.; Comelia, B.; Annett, M. and Reiner, H. (2004): Diagnostic Real-time PCR for detection of Salmonella in food. Appl. Environ Microbiol. 70(2): 235-244.

Cowan, S.T. and Steel, K. (1975): Manual for the identification of Medical Bacteria. Combridge Univ. Press London, New York. Malburne.

Edward, P.R. and Ewing, W.H. (1972): Identification of Enterobacteriaceae Minoapolis, Burgess, Publ. Co. Atlanta, USA.

Edris, A. (1993): Isolation and identification of E. coli and Salmonella from ready to eat meat products. Zag. Vet. Med. J. 21(2):187-193. 
Eleiwa, N.Z.H. (2003): Effect of chemical preservatives on food poisoning bacteria in some locally manufactured meat products ph.D. Thesis (Meat Hygiene), Fac. Vet. Med., Zagazig University.

FAO (1979): Food Agriculture Organization of the United Nations, Rome, manuals of food quality control, 4. Microbiological analysis, via delle terme dicaracalla, 00100 Rome, Italy.

Fathi, S.; El-Khateib, T.; Moustaf, S. and Hassanein, K. (1994): Salmonella Spp and pathogenic E. coli in some locally manufactured meat products. Assuit Vet. Med. J. 31(61):190-199.

Hassanien, FS. (2004): Bacterial hazarab associated with consumption of some meat products. Benha Vet. Med. J. 15:20.

Field, R.A.; Smith, F.C.; Denane, D.D.; Thomas, G.M. and Kotula, A.W. (1977): Sources of variation at the retail level in bacteriological condition of ground beef. J. Food Prot. 40(6): 385-388.

Frech, G. and Schwarz, S. (1998): Tetracycline resistance in Salmonella enterica subsp. Enterica Antimicrobial Agents and Chemotherapy, 42(5): 1288-1289.

Gebreyes, W.A.; Davies, P.R.; Turkson, P.K.; Morrow, W.E.; Funk, J.A. and Alter, T. (2004): Characterization of antimicrobial resistant phenotypes and genotypes among Salmonella enterica recovered from pigs on farms, from transport trucks and from pigs after slaughter J. Food Prot., 67(4): 698-705.

Gobran, R.A. (1985): Enterobacteriaceae in meat products in Upper Egypt. M.V.Sc. Thesis, Fac. Vet. Med. Assuit. Univ.

Guerra, B.; Soto, S.C. and Mendoza, M.C. (2000): Antimicrobial resistance and spread of class 1 integrons among Salmonella serotypes. Antimicrob. Agents Chemother. 44 (8): 2166-2169.

Harnai, K.; Satake, M. and White, T.J. (1997): Comparison of commercially available Kits for detection Salmonella strains in foods. Appli. Environ. Microbiol. 63: 775-778.

Hoorfar, J.; Ahrens, P. and Radstrom, P. (2000): Automated $5 \backslash$ nuclease PCR assay for identification of Salmonella enterica J. Clin. Microbial, 38: 3429-3435.

ICMSF (1978): International Commission on Microbiological Specification for Food Microorganisms in Foods Their significance and methods of enumeration. $1,2^{\text {nd }}$ Ed. Univ. of Toronto press, Toronto Onkarios.

Kimura, B.; Kawasaki, S.; Fujii, T.; Kusunoki, J.; Iton, T. and Flood, S.J. (1999): Evaluation of Taq Man PCR assay for detecting Salmonella in raw meat and shrimp. J. Food. Prot. 62: 329-335. 
Libby, J.A. (1975): Meat Hygiene, $4^{\text {th }}$ Ed. LEA and Febriger, Philadelphia. Livak, K.J.; Marmaro, J. and Flood, S.J. (1995): Guidelines for designing Taq Man PCR fluorogenic probes for $5^{\backslash}$ nuclease assaya. Perkin. Elmer Research News, AB1 Prism Sequence detection system.

Lubeck, P.S. and Hoorfar, J. (2003): PCR technology and applications to zoonotic food borne pathogens. Methods Mol. Biol. 216: 65-84.

Malorny, B.; Cook, N.; D Agostino, M.; DeMedici, D.; Croci, L.; Abdulm aujood A.; Fach, P.; Karpiskovo, R.; Aymerich, T.; KW Aitek, K. and Hoor Far, J. (2004): Multi-center validation of PCR-based method for detection of Salmonella in chicken J. AOCAC Int. 87: 861-866.

Malorny, B.; Hoorfar, J.; Hugas, M.; Heuvelink, A.; Fach, P.; Ellerborek, L.; Bunge, C.; Dorn, C. and Itelmuth, R. (2003): Inter-laboratory diagnostic accuracy of a Salmonella specific PCR-based methods. Int. J. Food Microbiol. 89: 241-249.

Mohamed, A.S. (1988): Salmonella in locally produced meat products M.V.Sc., Thesis (Meat Hygiene), Fac. Vet. Med. Cairo. Univ.

Mohamed, E.I. (2006): Detection of Salmonella Spp. in some meat products using recent techniques, M.V. Sci. Thesis, Meat hygiene, Fac. Vet. Med., Benha University.

Moussa, M.; Awad, H.; Yassien, M. and Gouda, H. (1993): Microbial quality of some meat products. Alex. Vet. Med. J. 41(3): 59-62.

NCCLS "National Committee for Clinical Laboratory Standards" NCCLS (2002): Performance standards for antimicrobial disk and dilutions susceptibility test for bacteria isolates from animals "Approved standards". $2^{\text {nd }}$ Ed., M31-2, NCCLS, Wayne, Pemsyl. Vania, USA.

Ouf, J.M. (2001): Microorganisms of sanitary importance in some meat products and their additives ph.D. Thesis (meat Hygiene), Fac. Vet. Med., Cairo University.

Paszko, K.; Rahn, K. and DeGrandis, S.A. (1997): The evaluation of fluorogenic polymerase chain reaction assay for the detection of Salmonella species in food commodities. Int. J. Food Microbiol. 35: 239-250.

Petra, F.G.; Wolffs, KariGiencross Romain Thibaudeau and Mansel WGriffiths (2005): Direct Quantitation and detection of Salmonella Spp. in biological samples without enrichment, using two-step filtration and Real-time PCR Canadian, Research Institute for food safety. 
Roa, N.M. and Nandy, S.C. (1977): Organisms of Enterobacteriaceae family associated with animal by-products Indian J., Anim. Sc. 47(6): 344-348.

Saleh, A.A. (1991): Hygienic and economic aspects of some microorganisms affecting production and quality of some meat products. M.V.Sc. Thesis (Meat hygiene). Fact. Vet. Med., Alex .University.

Tirado, C. and Schmidt, K. (2001): Wito surveillance programme for control of food borne infections and intoxications preliminary results and trends across greader Europe. J. Infect 43: 80-84.

Wiuff, C.; Madsen, M.; Baggesen, D.L. and Aaerstrup, E.M. (2000): Quinolone resistance among Salmonella enterica from cattle, broiters and swine in Denmark. Microbiol. Drug Resist., 6(1): 11-17. 